Цуй Чжэн - кандидат политических наук, доцент; заместитель директора Центра исследований экономики и политики стран с переходной экономикой Ляонинского университета, Китай (cz197897@sina.com)

\title{
ПОЛИТЭКОНОМИЧЕСКИЙ АНАЛИЗ КИТАЙСКО-РОССИЙСКИХ ВСЕСТОРОННИХ ОТНОШЕНИЙ СТРАТЕГИЧЕСКОГО ВЗАИМОДЕЙСТВИЯ И ПАРТНЕРСТВА В НОВУЮ ЭПОХУ
}

\begin{abstract}
Аннотация. В статье представлен анализ состояния китайско-российских отношений в последние годы. Автор подчеркивает новое позиционирование китайско-российских отношений на современном этапе с учетом новых геополитических факторов. В статье отмечаются значительные успехи в развитии экономического и торгового сотрудничества Китая и России, однако автор выделяет риски и проблемные точки, которые должны быть учтены и решены для продвижения процесса китайско-российского экономического и торгового развития.
\end{abstract}

Ключевые слова: Китай, Россия, стратегическое взаимодействие и партнерство, новая эпоха, трансграничная торговля, китайско-российское экономическое и торговое сотрудничество, «один пояс, один путь»

\section{Политический анализ}

Основные положения. Председатель КНР Си Цзиньпин во время своего визита в Россию в июне 2019 г. выдвинул отношения Китая и России на новый уровень связей двух стран, который получил название «всесторонних отношений стратегического взаимодействия и партнерства в новую эпоху». Слова «новая эпоха» сами по себе несут в себе два важных значения: во-первых, в настоящее время мир стоит перед лицом невиданных за последнее столетие перемен. Это означает, что сам мир вступает в новую эпоху. По этой причине китайско-российские отношения также встают перед лицом изменений и перед вопросом, каким образом реагировать на ситуацию в мире. Это объективно требует переориентации целей и позиций в китайско-российских отношениях. Во-вторых, и Китай, и Россия являются великими державами и постоянными членами Организации Объединенных Наций. Это оказывает серьезное влияние на изменения в мировой структуре, поэтому укрепление китайско-российских отношений важно не только для решения внутриполитических проблем двух стран (включая необходимость совместного развития экономики, достижения стабильности общества, предотвращения «цветных революций» и т.д.), но и для укрепления стабильности международного сообщества и установления нового мирового порядка. Председатель Си Цзиньпин отметил: «Совместное заявление об укреплении глобальной стратегической стабильности отражает дух ответственности Китая и России и позитивные результаты стратегического

\footnotetext{
1 Данная статья является промежуточным результатом исследования проекта «Основные коррективы и последствия внешней политики России после возвращения В. Путина на пост президента Российской Федерации» (LNUJD201702) при Ляонинском университете на базе гуманитарных и социологических исследований Министерства образования КНР «13-я пятилетняя программа» и проекта Фонда общественных наук провинции Ляонин «Исследование роли России в китайскоамериканских конкурентных отношениях в период правления Д. Трампа» (L17BGJ004).
} 
взаимодействия двух стран. В текущих условиях это имеет особое значение»1. Одним словом, новое позиционирование китайско-российских отношений играет значительную роль на международной арене.

Основные условия для продвижения китайско-российских всесторонних отношений стратегического взаимодействия и партнерства в новую эпоху. На сегодняшний день китайско-российские отношения находятся в лучшем периоде за всю историю и демонстрируют все более усиливающуюся тенденцию, которая обеспечивает благоприятные политические условия для развития торгово-экономического сотрудничества между двумя странами. Также следует отметить, что в 2018 г. товарооборот между Китаем и Россией превысил отметку в 100 млрд долл., а в 2019 г. отмечается 70-летие установления дипломатических отношений между Китаем и Россией. В целях консолидации и дальнейшего развития китайско-российских всесторонних отношений стратегического взаимодействия и партнерства в новую эпоху Китай и Россия пытаются еще больше повысить уровень торгово-экономического сотрудничества.

С точки зрения экономической ситуации укрепление торгово-экономического сотрудничества способствует экономическому развитию обоих государств. Китайская экономика переходит с этапа быстрого роста на этап качественного развития, что является важным пунктом на пути к структурной экономической перестройке. В течение этого периода темпы экономического роста замедлятся, но будут поддерживаться на определенном уровне, внутренний спрос будет расти, а спрос на энергию и другие ресурсы не будет уменьшаться. Российская экономика также начала улучшаться. Планируется, что российская экономика станет 5-й по величине экономикой в мире к 2024 г. Так как Россия столкнулась с экономическими санкциями Запада, в течение последних нескольких лет она акцентировала внимание на развитии реальной экономики, специальных отраслей обрабатывающей промышленности, создании агропромышленного комплекса. Вследствие этого «экономическое развитие Китая и России сталкивается с переходом на новую модель, которая характеризуется принципами “высокая эффективность, высокая производительность и высокая добавленная стоимость”. В будущем экономическом сотрудничестве, с развитием науки и техники и структурной экономической перестройкой, обе стороны будут углублять интеграцию своих ресурсов, координировать экономическую структуру и осуществлять региональное развитие, обогащать взаимное сотрудничество, формировать новую эффективную модель китайско-российского экономического сотрудничества, которая будет приносить обеим сторонам взаимную выгоду и положительные результаты» 2 .

\section{Экономический анализ}

Оценка роста объема трансграничной торговли между Китаем и Россией в 20182. свыше 100 млрд долларов США. Товарооборот между Китаем и Россией в 2018 г. достиг 108,779 млрд долл. США, увеличившись на 26\% по сравнению с предыдущим годом. Экспорт из России в Китай составил 56,076 млрд долл. США, что составило 12,5\% общего объема экспорта. В Россию из Китая было ввезено продукции на сумму 52,203 млрд долл. США, что составляет $22 \%$ общего объ-

\footnotetext{
1 习近平 : 70 年是里程碑也是新起点. 人民网. 2019年6月6日 [Си Цзиньпин: 70 лет - знаменательный момент и новая отправная точка: интернет-версия «Жэньминь жибао». 6 июня 2019 г.]. Доступ: http:// world.people.com.cn/n1/2019/0606/c1002-31123591.html (проверено 24.02.2020).

2 史春阳. 进一步深化中俄经贸合作. 中国社会科学网. 2019年2月14日 [Ши Чуньян. Дальнейшее углубление китайско-российского экономического и торгового сотрудничества. Китайская сеть социальных наук. Сайт Академии общественных наук Китая. 14 февраля 2019 г.]. Доступ: http://www. cssn.cn/zx/bwyc/201902/t20190214_4825053_1.shtml (проверено 24.02.2020).
} 
ема импорта. Торговый профицит России с Китаем составляет 3,87 млрд долл. США. Китай во внешней торговле России занимает 1-е место с 2010 г. и сохраняет этот статус в течение 9 лет подряд. В 2018 г. товарооборот между Россией и Китаем превысил отметку в 100 млрд долл. и достиг самого высокого показателя в истории ${ }^{1}$. В определенном смысле можно сказать, что психологические барьеры в вопросе торговли между двумя странами были преодолены.

Далее приводятся авторские соображения по этому вопросу.

1. В 2018 г. объем торговли между двумя странами превысил 100 млрд долл. США. Следует сказать, что это большой шаг и серьезный прогресс в китайско-российских экономических и торговых отношениях, а также долгосрочная цель, которой Китай и Россия планировали достичь. В этом смысле можно назвать этот результат прорывом, который должен быть закреплен.

2. Этот результат является следствием постепенного развития торговли между двумя странами в последние годы. Как упоминалось выше, в 2017 г. объем товарооборота достиг 86,96 млрд долл. Согласно стоимостным показателям, в 2018 г. товарооборот между двумя странами увеличился на $26 \%$ по сравнению с предыдущим годом, тем не менее с точки зрения меновой торговли рост экспорта российских нефтегазовых ресурсов несколько ниже и составляет 20,2\%. То же самое относится и к другим продуктам: например, в долларах США экспорт из России в Китай увеличился на 44\%, а в реальном выражении - только на $14 \%$. Поэтому резкий рост китайско-российской торговли в 2018 г. во многом связан с изменением курса рубля и более высокими темпами роста цен на энергоресурсы в 2018 г.

3. В 2018 г. китайско-российские экономические и торговые отношения не только достигли впечатляющих результатов, но и создали новые точки роста торговли. Российский экспорт продовольствия и сельскохозяйственного сырья в Китай в 2018 г. составил 52,31 млрд долл. США, увеличившись по сравнению с предыдущим годом на $26 \%$, и стал третьей основной категорией российского экспорта в Китай. Обе страны также представили новые разработки в области электронной коммерции и организации рынка услуг.

4. Активно развивалось сотрудничество в ряде крупных стратегических проектов, таких как энергоресурсы, ядерная промышленность, освоение космоса, развитие инфраструктуры нейтральных территорий, а также в новых областях, таких как освоение Северного полюса, цифровая экономика и др. В совместной работе над этими проблемами страны также достигли определенного прогресса.

Перспективы развития китайско-российского торгово-экономического сотрудничества. Ради укрепления и дальнейшего развития партнерских отношений и стратегического взаимодействия и Китай, и Россия стараются и дальше развивать экономические и торговые отношения как экстенсивно, так и интенсивно.

Исходя из текущей ситуации и будущих прогнозов, существует много факторов, способствующих развитию сотрудничества между Китаем и Россией. Это проявляется в следующем.

Во-первых, как уже упоминалось ранее, Китай и Россия сталкиваются со сложной международной обстановкой, а в будущем ситуация будет только ухудшаться. Это благоприятный глобальный фактор для развития китайскороссийского сотрудничества. Во-вторых, сейчас лучший период в истории китайско-российских отношений, и это также обеспечивает благоприятные политические условия для развития торгово-экономического сотрудничества

\footnotetext{
1 崔铮,王亚洁.全球政经大变局下的中俄合作.新华网. 2019年10月24日 [ЦуйЧжэн, Ван Яцзе. Китайскороссийское сотрудничество в условиях глобальных политических и экономических изменений. Xinhuanet. 24 октября 2019 г.]. Доступ: http://www.xinhuanet.com/globe/2019-10/24/c_138470422.htm (проверено 24.02.2020).
} 
между двумя странами. В-третьих, после того, как Владимир Путин победил на выборах в марте 2018 г., появилась потребность в решении многих срочных проблем, в основном экономических. А решение экономических проблем требует большого объема капиталовложений. В президентском обращении 2016 г. Путин отметил, что главная проблема российской экономики заключается в «дефиците инвестиционных ресурсов» ${ }^{1}$. Вопрос в том, где взять средства, необходимые для решения экономических проблем? Фундаментальным путем решения финансовой проблемы является развитие экономики, однако текущее состояние и будущее развитие экономики зависит от объема инвестиций, который нужно увеличивать. Это трудно решить в краткосрочной перспективе. Россия стремится к привлечению иностранных инвестиций, постоянно улучшая инвестиционную среду и активно участвуя в реализации инициативы «Один пояс, один путь». Можно сказать, что это увеличивает вероятность привлечения китайских инвестиций.

Некоторые когнитивные проблемы, которые требуют своего решения в иелях продвижения процесса китайско-российского экономического и торгового развития.

1. Существенных изменений в торговой структуре не произошло. В 2018 г. экспорт нефти и других сырьевых товаров из России в Китай составил $80 \%$ общего объема всего экспорта государства. В этом году Россия экспортировала в Китай 71,49 млн т нефти, что на 19,7\% больше, чем в прошлом году2 ${ }^{2}$ Проблема в том, что международные тарифы на нефть безжалостны, как американские горки. Они зависят не только от спроса и предложения, но и от политических и спекулятивных факторов. Поэтому упор на сотрудничество в нефтегазовой сфере для обеспечения дальнейшего развития китайско-российских торгово-экономических отношений не является надежным путем.

2. В рамках реализации инициативы «Один пояс, один путь» китайско-российское сотрудничество в области инфраструктуры не достигло значительных успехов. В последнее время сообщается, что проект высокоскоростного железнодорожного сообщения из Москвы в Казань может быть приостановлен по двум причинам. Одна из них связана с плохой экономической ситуацией в России и недостаточным объемом капиталовложений. В постройку железной дороги необходимо вложить 24 млрд долл. Даже при поддержке некоторых китайских фондов Россия не может позволить себе вкладывать столько денег в железную дорогу. Другая причина - это то, что Россия сомневается в должном обеспечении пассажиропотока железной дороги. Из-за высокой стоимости высокоскоростного железнодорожного транспорта цена билета также обречена быть высокой. В этом случае россияне будут выбирать более дешевые способы передвижения, что неизбежно скажется на пассажиропотоке. Согласно историческому опыту, большие проекты, например строительство моста Хэйлунцзян или моста Тунцзян, были отложены на много лет еще до начала реализации. Поэтому после подписания соглашений по некоторым крупным инфраструктурным проектам Китай и Россия не так легко начинают процесс реализации. По материалам «Российской газеты», опубликованным 29 декабря 2017 г., Китай в данный момент реализует 28 проектов общей стоимостью 4 млрд долл. США на Дальнем Востоке России. Проекты реализуются в разных областях, включая транспорт и логистику, туризм, лесное хозяйство, развитие энергетики, глубо-

\footnotetext{
1 Послание Президента Федеральному Собранию. 1 декабря 2016 г. Доступ: http://www.kremlin.ru/ events/president/news/53379\#sel=76:55:Wai,76:57:iaW (проверено 24.02.2020).

2 陆南泉. 俄罗斯经济 : 复杂又艰难的一年. 经济观察网. 2016年2月1日 日Лу Наньцюань. Российская экономика: сложный и трудный год. Экономическое наблюдение. 1 февраля 2016 г.]. Доступ: http:// www.eeo.com.cn/2016/0201/282907.shtml (проверено 24.02.2020).
} 
кую переработку стали и многие другие. В 2017 г. был также создан Китайскороссийский фонд регионального развития с активом в 100 млрд юаней. За последние два года $80 \%$ азиатско-тихоокеанских инвестиций в дальневосточную экономику были внесены Китаем ${ }^{1}$.

Будут ли эти проекты последовательно реализованы? Это вопрос, достойный внимания. Все помнят, что программа сотрудничества между регионами Дальнего Востока и Восточной Сибири РФ и северо-востока КНР была сформулирована совместно Китаем и Россией в марте 2007 г. и предусматривала реализацию 194 крупных и малых проектов. Однако подавляющая часть проектов не были реализованы. Именно по этой причине инвестиции со стороны Китая ограничены. В 2016 г. доля инвестиций в Россию по китайской программе инвестирования в странах, связанных с инициативой «Один пояс, один путь», составила 8,4\%. В 2015 г. этот показатель составлял 16\%. В 2016 г. инвестиции Китая в России сократились вдвое по сравнению с предыдущим годом и составили всего 1,29 млрд долл. США².

3. Взаимное политическое доверие между Китаем и Россией также нуждается в дальнейшем укреплении. В последние годы в России ослабевает мнение о Китае как о «территориальной угрозе», но отдельные эпизоды все еще присутствуют. Не так давно разгорелось недовольство по поводу китайской гидроэлектростанции на Байкале. Согласно новостям, более 50 городов России провели антикитайские демонстрации. Такие эпизоды неизбежно заставят китайские компании задуматься о безопасности инвестиций в России, что, естественно, сократит объем инвестируемых средств.

Cui Zheng, Cand.Sci. (Pol.Sci.), Associate Professor, Deputy Director of the Center for Economic and Political Studies of Transition Economies, Liaoning University, China (cz197897@sina.com)

\title{
POLITICAL ECONOMIC ANALYSIS OF SINO-RUSSIAN COMPREHENSIVE RELATIONS OF STRATEGIC INTERACTION AND PARTNERSHIP IN THE NEW ERA
}

\begin{abstract}
The article presents an analysis of the state of Sino-Russian relations in recent years and emphasizes new positioning of Sino-Russian relations at the present stage, taking into account new geopolitical factors. The author notes significant successes in the development of economic and trade cooperation between China and Russia, but also shows risks and problems to be taken into account and resolved to advance the process of Sino-Russian economic and trade development.
\end{abstract}

Keywords: China, Russia, strategic interaction and partnership, new era, cross-border trade, Sino-Russian economic and trade cooperation, "one belt, one way»

1 Дробышева И. От локальных проектов к трансграничной кооперации. - Российская газета. 29.12.2017. Доступ: https://rg.ru/2017/12/29/kitaj-realizuet-na-dalnem-vostoke-28-proektov-na-4-mlrddollarov.html (проверено 24.02.2020).

2 中国对外投资合作发展报告 ( 2013-2017) ,中华人民共和国商务部 [Отчет о развитии сотрудничества в сферах иностранных инвестиций Китая. 2013-2017 гг. Министерство коммерции КНР]. Доступ: http://fec.mofcom.gov.cn/article/tzhzcj/tzhz/ (проверено 24.02.2020). 